\title{
Star wars X-ray lasers were oversold, says Woodruff
}

\section{San Francisco}

Physicists Edward Teller and Lowell Wood misled United States policymakers with "overly optimistic and technically incorrect statements" about X-ray laser research for the Strategic Defense Initiative (SDI), according to Roy Woodruff, former director of the X-ray laser project at Lawrence Livermore Laboratory, Woodruff left his directorship in 1985 because, he says, he knew he was not able to deliver what Teller was promising.

The allegations, made in a confidential grievance letter sent by Woodruff to University of California (UC) president David Gardner last April, were leaked to the press just as Woodruff's own dispute with the Lawrence Livermore Laboratory appears to be over (see below). Woodruff, a keen supporter of SDI, regards the release of the confidential letter, by the Southern California Federation of Scientists (SCFS), an anti-SDI group with which he has no connection, as being "totally inappropriate".

In the letter, Woodruff claims that laboratory director Roger E. Batzel knew of the inaccuracies presented to government officials by Teller, co-founder and former director of the laboratory, and Wood, a laboratory division head, but "refused to transmit correcting technical information or allow me to do so."

Because the information is classified,
Woodruff's letter does not reveal the specific criticisms he made. But some Livermore scientists say Teller and Wood vastly underestimated the time necessary to perfect an X-ray laser system, and met with President Reagan and members of Congress on several occasions to promote the research and lobby for increased funding for SDI.

SCFS decided to release the letter now, according to Robert M. Nelson, co-chairman of SCFS, because budget decisions on SDI funding are being made in Congress. Nelson recalled President Reagan's speech last October, after the collapse of the Reykjavik summit, in which he said scientists were convinced that a spacebased anti-weapon system could be deployed "several years down the road." If that was the President's thinking, said Nelson, "I would have been unfaithful to my responsibility as a citizen, not to make this information known."

Nelson said SCFS hopes for an outside investigation by an "appropriate agency," and it may get its wish. Woodruff was called on to give a classified briefing to interested members of Congress, on 23 October.

An aide to representative George Brown $\mathrm{Jr}$, who requested the briefing, said a congressional investigation may ensue, to evaluate whether Congress has been operating under erroneous assumptions about SDI.

Marcia Barinaga

\section{Weapons researchers' right to dissent upheld}

\section{San Francisco}

IN an action that backs the right of US nuclear weapons laboratory employees to voice dissenting views, the University of California (UC) has settled a personnel grievance filed by Lawrence Livermore Laboratory scientist Roy Woodruff.

Woodruff, who resigned in October 1985 as director of the laboratory's X-ray laser programme, claims he has been treated as "an un-person in a windowless office" and has not been given assignments that make use of his skills.

The university, contracted by the government to manage the Lawrence Livermore and Los Alamos National Weapons Laboratories, refused to hear Woodruff's first grievance, filed on 3 April, in which he criticized Lawrence Livermore Laboratory director Roger Batzel for refusing to correct "overly optimistic" representations of X-ray laser research made to President Reagan by physicist Edward Teller (see above).

A second grievance, filed by Woodruff on 30 April, requested simply that the laboratory reinstate him in a position of responsibility commensurate with his scientific skills. A committee of 3 members of the laboratory's technical and management staff heard Woodruff's case, and UC President Gardner accepted their recommendation that Woodruff's status be improved.

In a letter to Woodruff dated 20 October, Gardner said he was instructing the laboratory to find a suitable position for Woodruff within its defence programmes.

UC has been criticized for not taking a more active role in managing the weapons laboratories (see Nature, 329, 275; 1987), and Gardner's move has some bearing on the debate. Woodruff claims his treatment over the past year has been a form of reprisal for his disagreement with Batzel.

He believes the freedom to dissent is essential to the laboratory's role in advising the administration, and pointed to a recent paper by Livermore scientist Christopher Cunningham, that cast doubt on the viability of kinetic kill weapons (see Nature 328,657 ; 1987). Marcia Barinaga

\section{AIDS drug gets green light}

\section{Washington}

THE controversial drug ribavirin, developed by ICN Pharmaceuticals for the treatment of AIDS (acquired immune deficiency syndrome), has been put back on track by the US Food and Drug Administration (FDA), in a surprise reverse decision. The FDA has approved clinical trials in humans of ICN's ribavirin, tradenamed Virazole, despite the strong reservations voiced earlier by the agency that the drug was inefficacious and produced harmful side effects.

Ribavirin is a guanosine analogue that ICN says has shown promise in preventing the progression of lympadenopathy syndrome (LAS) to full-blown AIDS in those infected with the AIDS virus. The drug has been controversial since its development, and the FDA has twice rejected ICN's application to enter clinical trials this year. At the Third International Conference on AIDS in Washington, DC in June, FDA Commissioner Frank Young stood up at the end of ICN's presentation of early clinical data, and issued a statement that the FDA had not approved ribavirin for use in humans, and that ICN had yet to give the agency evidence of the drug's effectiveness.

The FDA's reluctance to allow ICN to proceed with human trials of ribavirin has been criticized by gay rights groups and other AIDS activists as quibbling over details. In a move sympathetic to AIDS sufferers, the California state legislature passed a bill in September to side-step the FDA approval process and authorize tests of any experimental AIDS drug manufactured in the state on its own, including ICN's ribavirin.

ICN has drawn criticism from members of Congress and the FDA for trying to accelerate the approval process by releasing early data to the media. The company held a press conference last January to announce its data on the drug's effect in prolonging the progression of AIDS despite FDA suggestions that the conference be postponed until the results could be properly assessed.

ICN approached the FDA in its third application for clinical trials with a redesigned protocol and additional data on ribavirin's safety. In his announcement of approval of the drug for clinical trials, Young said the safety considerations were no longer of "sufficient magnitude" to prevent tests in humans from going forward. Although new FDA regulations permit drug manufacturers to sell drugs for life-threatening diseases during Phase II clinical trials, FDA has indicated that ribavirin may not be administered outside the clinical tests.

Carol Ezzell 